\title{
Intracellular Ser/Thr/Tyr phosphoproteome of the oral commensal Streptococcus gordonii DL1
}

\author{
Carolina Robertsson ${ }^{1^{*}}$ D, Gunnel Svensäter ${ }^{1}$, Zoltan Blum² and Claes Wickström ${ }^{1}$
}

\begin{abstract}
Background: To respond and adapt to environmental challenges, prokaryotes regulate cellular processes rapidly and reversibly through protein phosphorylation and dephosphorylation. This study investigates the intracellular proteome and Ser/Thr/Tyr phosphoproteome of the oral commensal Streptococcus gordonii. Intracellular proteins from planktonic cells of S. gordonii DL1 were extracted and subjected to 2D-gel electrophoresis. Proteins in general were visualized using Coomassie Brilliant Blue and T-Rex staining. Phosphorylated proteins were visualized with ProQ Diamond Phosphoprotein Gel Stain. Proteins were identified by LC-MS/MS and sequence analysis.

Results: In total, sixty-one intracellular proteins were identified in S. gordonii DL1, many of which occurred at multiple isoelectric points. Nineteen of these proteins were present as one or more Ser/Thr/Tyr phosphorylated form. The identified phosphoproteins turned out to be involved in a variety of cellular processes.

Conclusion: Nineteen phosphoproteins involved in various cellular functions were identified in S. gordonii. This is the first time the global intracellular Ser/Thr/Tyr phosphorylation profile has been analysed in an oral streptococcus. Comparison with phosphoproteomes of other species from previous studies showed many similarities. Proteins that are consistently found in a phosphorylated state across several species and growth conditions may represent a core phosphoproteome profile shared by many bacteria.
\end{abstract}

Keywords: 2DE, Oral bacteria, Phosphoproteome, Pro-Q diamond, Streptococci, Streptococcus gordonii

\section{Background}

Streptococcus gordonii is a pioneer oral colonizer, involved in the establishment of oral biofilms [1]. Due to the numerous different adhesins expressed on its surface, $S$. gordonii cells readily attach to and colonize dental surfaces [2]. Moreover, S. gordonii can passively migrate from small oral lesions through the blood stream and cause infective endocarditis by opportunistic infection of the heart valves [3]. This mainly saccharolytic species is considered a commensal with ubiquitous habitation in humans, and given the acid production and

\footnotetext{
* Correspondence: carolina.robertsson@mau.se

${ }^{1}$ Department of Oral Biology and Pathology, Faculty of Odontology, Malmö University, 20506 Malmö, Sweden

Full list of author information is available at the end of the article
}

acid tolerance of S. gordonii, it prevails at the acidic conditions that periodically occur in oral biofilms [4-6]. When carbohydrate concentrations are low, S. gordonii like other oral streptococci utilizes a carbohydrate phosphotransferase transport system (PTS) with high glucose affinity [7]. Upon spikes in carbohydrate concentration, oral streptococci are at risk for "sugar killing" from damaging effects caused by accumulated glycolytic intermediates [8]. To evade such inflictions, oral streptococci switch to carbohydrate transport systems with lower affinity for glucose, e.g. the permease system. The glycolytic rate can also be regulated by switching to alternative pathways, e.g. through activation of lactate dehydrogenase (ldh) in pyruvate conversion for faster regeneration of $\mathrm{NAD}^{+}[9]$. In this way, cells reduce glucose

(c) The Author(s). 2020 Open Access This article is licensed under a Creative Commons Attribution 4.0 International License, which permits use, sharing, adaptation, distribution and reproduction in any medium or format, as long as you give appropriate credit to the original author(s) and the source, provide a link to the Creative Commons licence, and indicate if changes were made. The images or other third party material in this article are included in the article's Creative Commons licence, unless indicated otherwise in a credit line to the material. If material is not included in the article's Creative Commons licence and your intended use is not permitted by statutory regulation or exceeds the permitted use, you will need to obtain permission directly from the copyright holder. To view a copy of this licence, visit http://creativecommons.org/licenses/by/4.0/ The Creative Commons Public Domain Dedication waiver (http://creativecommons.org/publicdomain/zero/1.0/) applies to the data made available in this article, unless otherwise stated in a credit line to the data. 
uptake as well as drain themselves of glycolytic intermediates by producing large amounts of lactic acid. In addition, oral streptococci employ strategies colloquially termed as the "acid tolerance response" (ATR) that enhance cell survival in acidic environments [4, 10, 11]. The ATR is dependent on molecular chaperone activity $[4,8]$ that sustains correct protein folding during biosynthesis even at low $\mathrm{pH}$.

To keep up with environmental fluctuations, prokaryotes have been suggested to regulate the activity of proteins involved in the central carbon metabolism rapidly and reversibly through phosphorylation and dephosphorylation mechanisms $[12,13]$. The reversible regulatory phosphorylation events operate on a much faster time scale than changes in protein expression [14]. The earliest studies on protein phosphorylation and dephosphorylation as regulatory events in bacteria focused on phosphorylation of histidine and aspartate residues in relation to two-component systems [15]. However, phosphorylation events on serine, threonine, and tyrosine (Ser/Thr/Tyr) have also been found to play important roles in prokaryotic intracellular signalling. Although the most common group of Ser/Thr kinases (i.e. Hanks-type kinases) are often referred to as "eukaryotic kinases", many prokaryotic Ser/Thr kinases also belong to this group [16]. There are many examples of phosphorylation events regulating cellular activities in bacteria, relating to house-keeping functions as well as stress responses and virulence $[12,17,18]$. In Lactobacillus rhamnosus, phosphorylation of glycolytic enzymes is upregulated as a response to acidic stress [19]. In that study, the phosphorylation state of threonine and serine residues on glyceraldehyde 3-phosphate dehydrogenase (gapdh) differed between protein species depending on the growth conditions, while the overall abundance of the different proteins remained unchanged. This supports the idea that phosphorylation can regulate enzyme activity separately from regulation of gene expression. Different forms of the same protein may display increased or decreased catalytic activity, altered subcellular localization, or modified interaction with non-substrates [20, 21]. Multisite phosphorylation can coordinate several such effects, determine the duration of a response, or mediate signal integration [21]. Protein phosphorylation may also completely alter the biological functions of proteins in the cell, a phenomenon referred to as protein moonlighting [22]. The regulatory effects of phosphorylation events on specific enzymes have been studied in some oral bacteria, mainly the oral streptococci [23-25], but to the best of our knowledge, global Ser/Thr/Tyr phosphorylation profiles of $S$. gordonii have not yet been detailed. The aim of the current study was to identify the intracellular protein expression profile, with special attention to Ser/Thr/Tyr phosphorylated proteins, in S. gordonii DL1.

\section{Results}

\section{General protein expression profile}

Intracellular proteomes from planktonic cells of $S$. gordonii DL1 were extracted and separated by 2DE. The total intracellular proteome was visualized with Coomassie Brilliant Blue stain (Sigma). In total, 222 protein spots were detected. Discrete spots were manually excised for identification with LC-MS/MS. Molecular weights (MWs) and isoelectric points (pIs) for identified proteins were estimated from the gels as well as gathered from the mass spectrometry data. MWs, pIs, MASCOT scores, number of matched peptides and \% coverages are listed in Table 1. The sequenced peptides identified by LC-MS/MS can be found in supplemental material (Additional file 1). In total, 61 proteins were identified, many of which were present at multiple isoelectric points (Fig. 1, Table 1).

\section{Intracellular Ser/Thr/Tyr phosphorylation profile}

Spots containing Ser/Thr/Tyr phosphorylated proteins were visualized with Pro-Q Diamond stain and phosphoimaging. The total intracellular proteome was visualized with T-Rex protein labelling for orientation of the phosphorylated spots. In total, 49 phosphorylated spots were detected. These were generally found on the acidic side of the 2DE gels (Fig. 2).

Phosphorylated protein spots where identified with LC-MS/MS (Table 1). Six of the 49 phosphorylated spots remained unidentified, due to a lack of significant hits from the Mascot search (four spots) or absence from Coomassie gels, preventing excision for identification (two spots). In total, 19 putative Ser/Thr/Tyr phosphorylated proteins were identified, see Table 1.

\section{Cellular processes associated with Ser/Thr/Tyr phosphorylated proteins}

The proteins detected as Ser/Thr/Tyr phosphorylated are involved in various cellular processes (Fig. 3). All phosphoproteins involved in the carbon metabolism, except for HPr and tpi, were present as more than one phosphorylated species, occurring at different $\mathrm{p} I \mathrm{~s}$ on the gels. HPr and tpi were also present as one additional, non-phosphorylated species respectively (Figs. 1 and 2, Table 1). Pfk and pgm were both present as two species each, all phosphorylated. Enolase was identified in both unphosphorylated and phosphorylated forms. Four of the phosphorylated enolase species were found at the expected MW. Pyk was present as four adjacent species, two of which were phosphorylated. Eight spots were identified as gapdh, three of which were phosphorylated. Nine species of pgk were identified, of which three were phosphorylated. Three species of ldh were identified, two phosphorylated. Six phosphorylated proteins involved in biosynthesis were identified. Deob, pgam and 


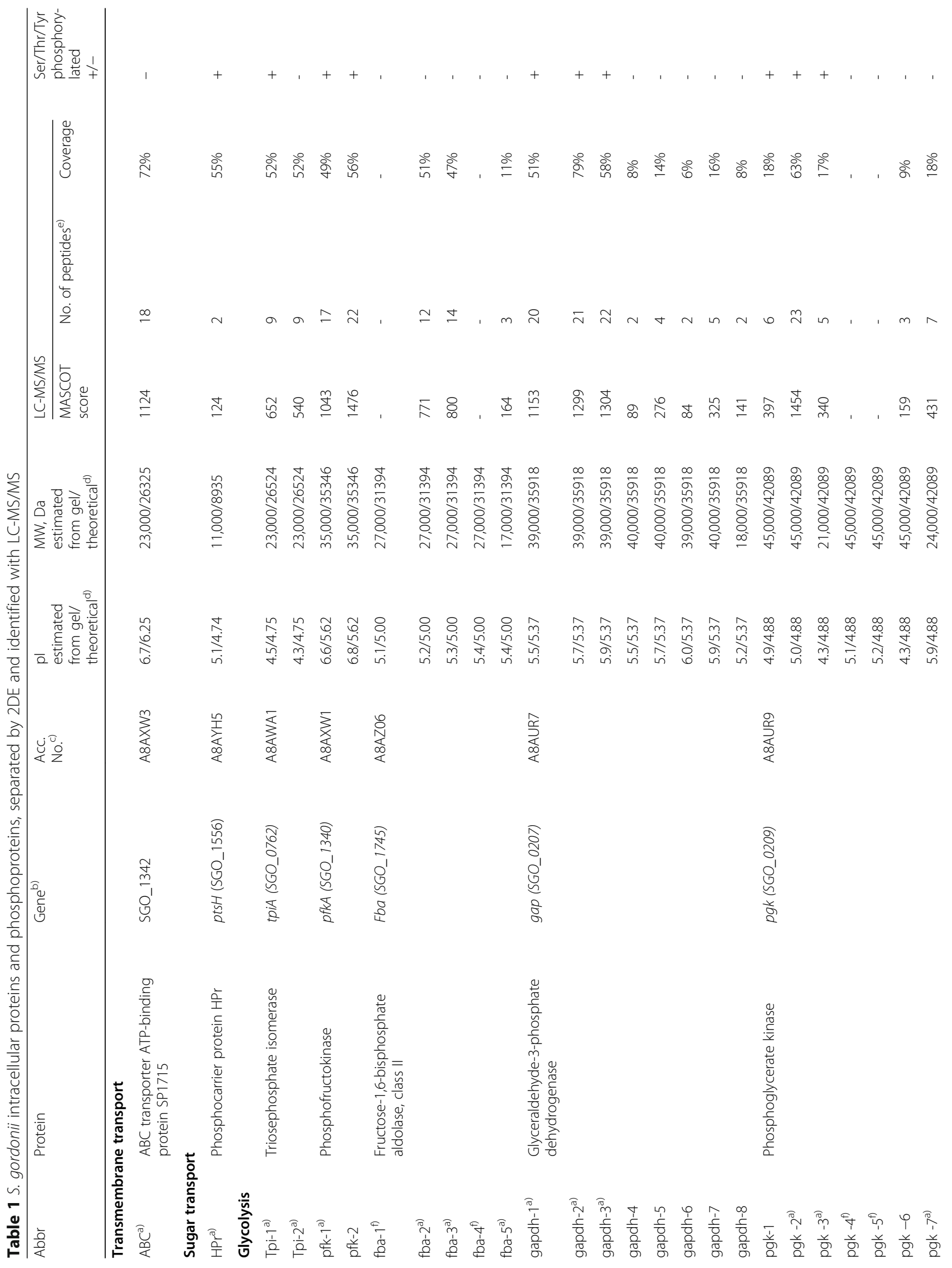




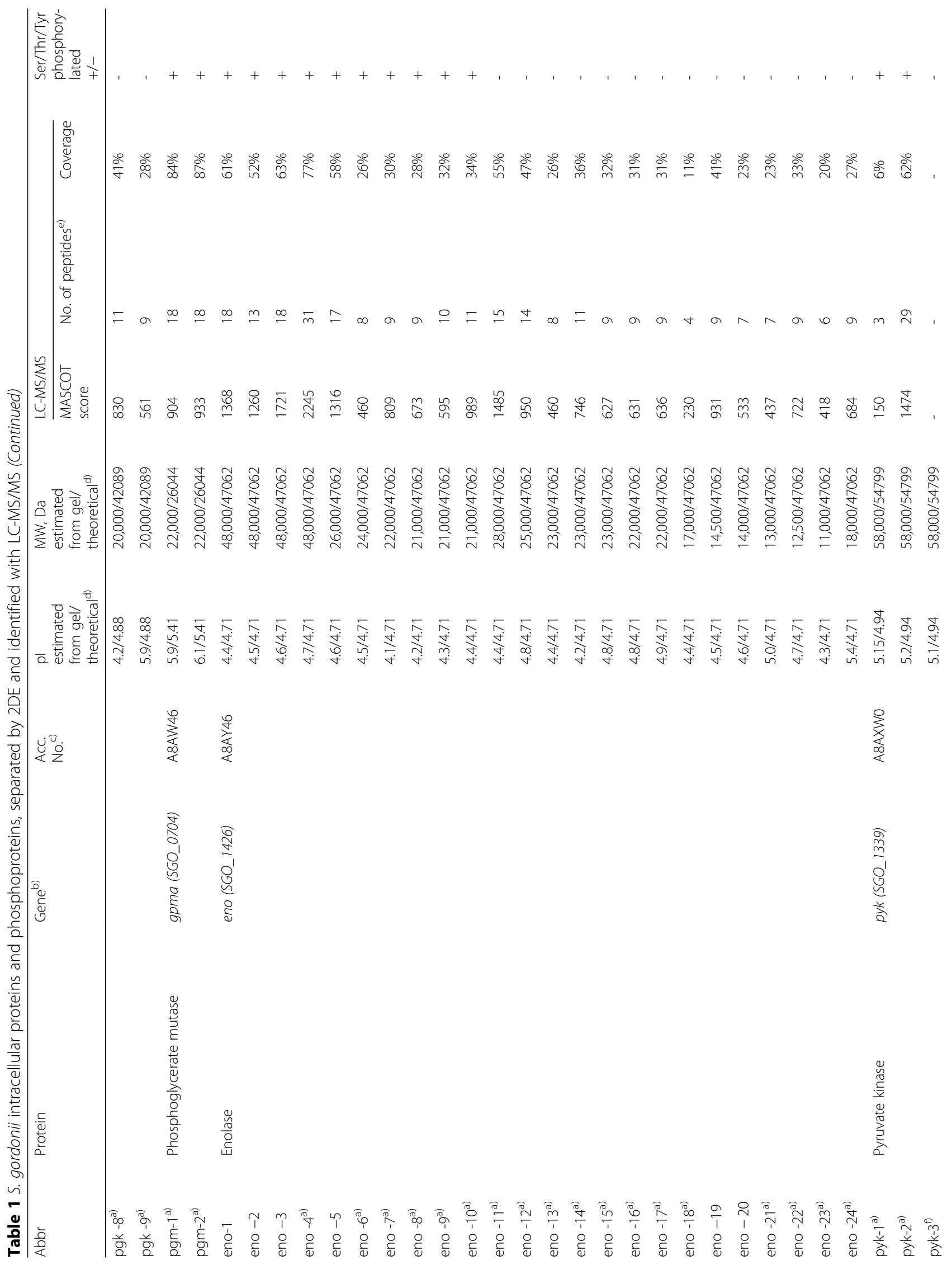




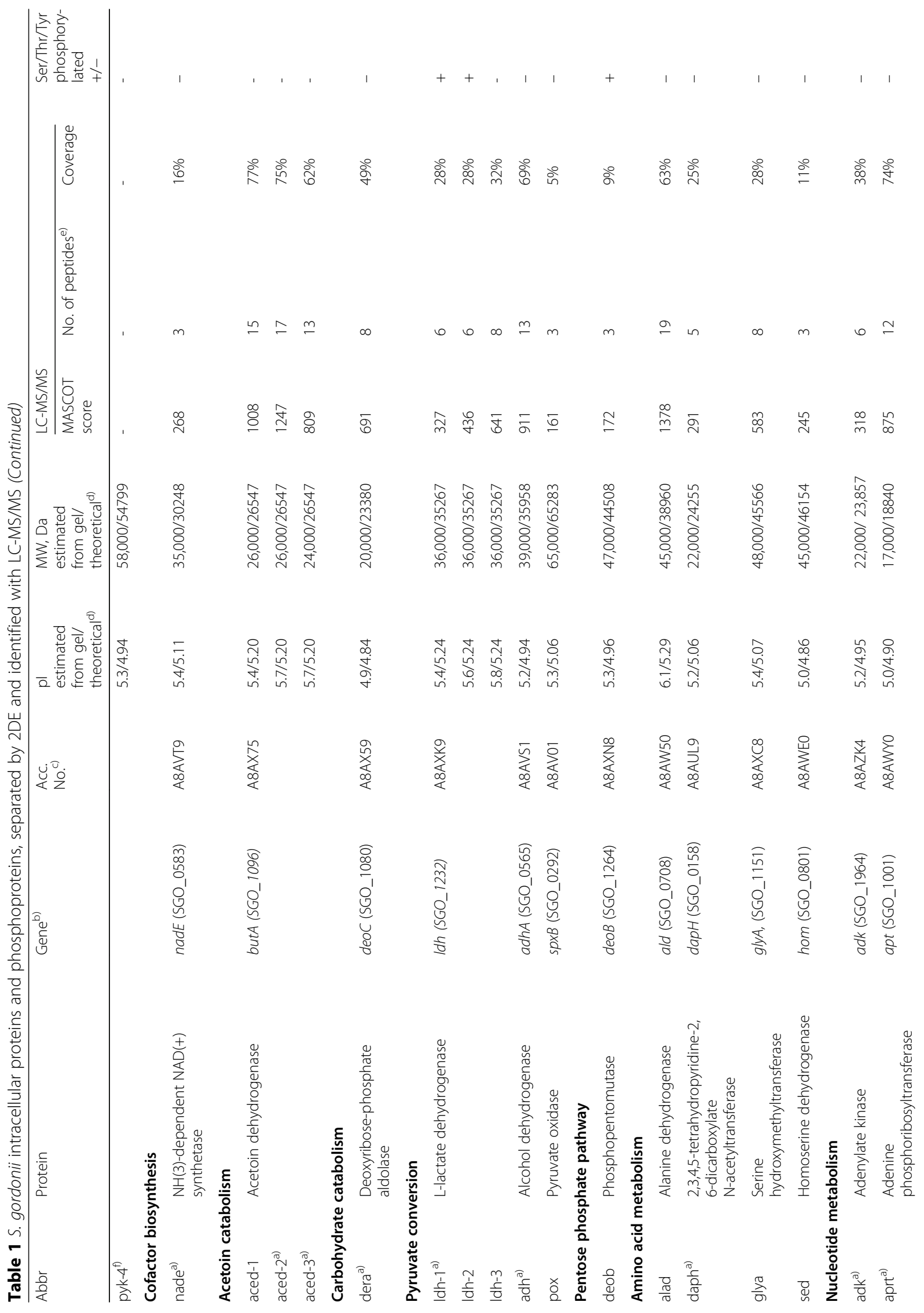




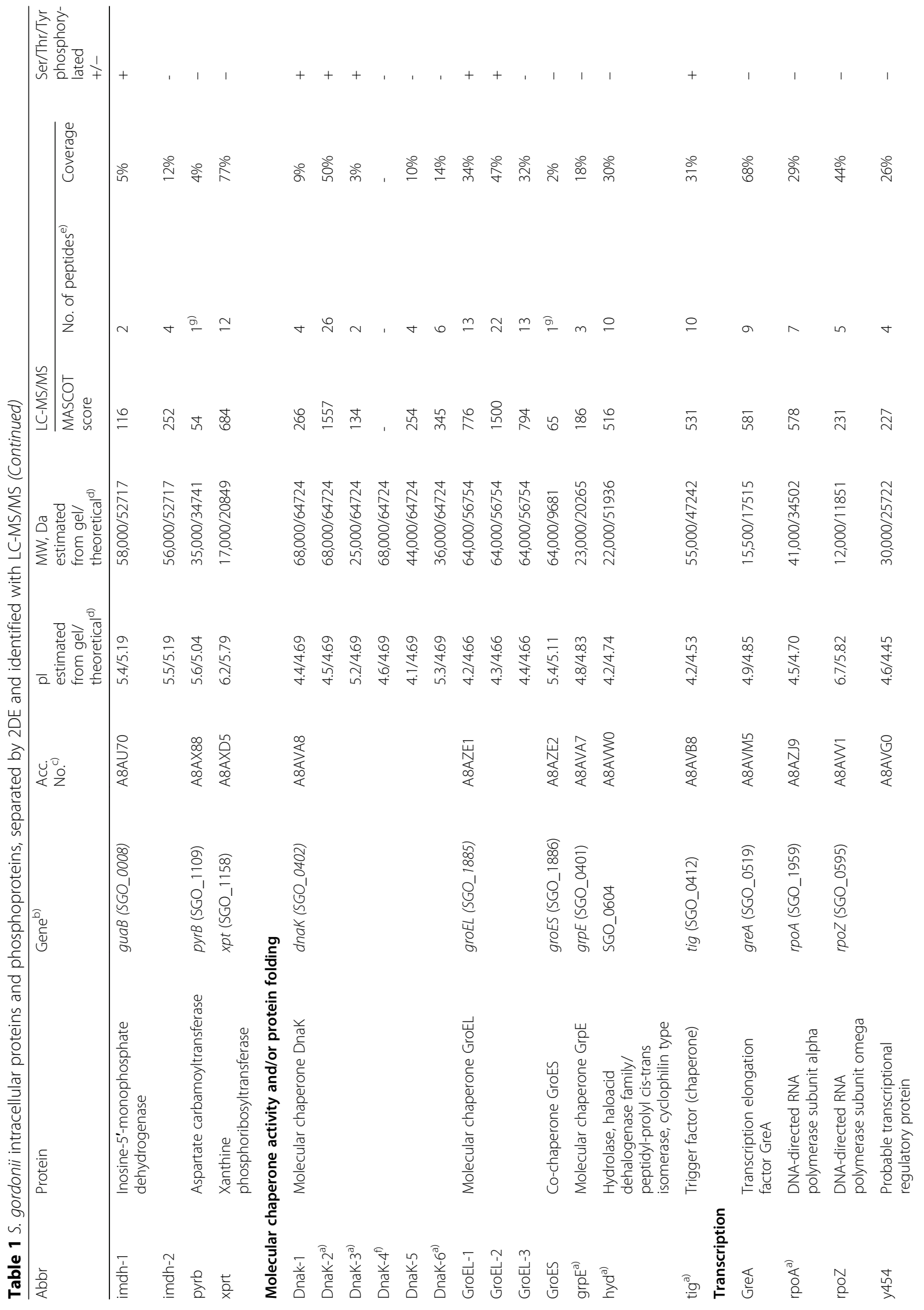




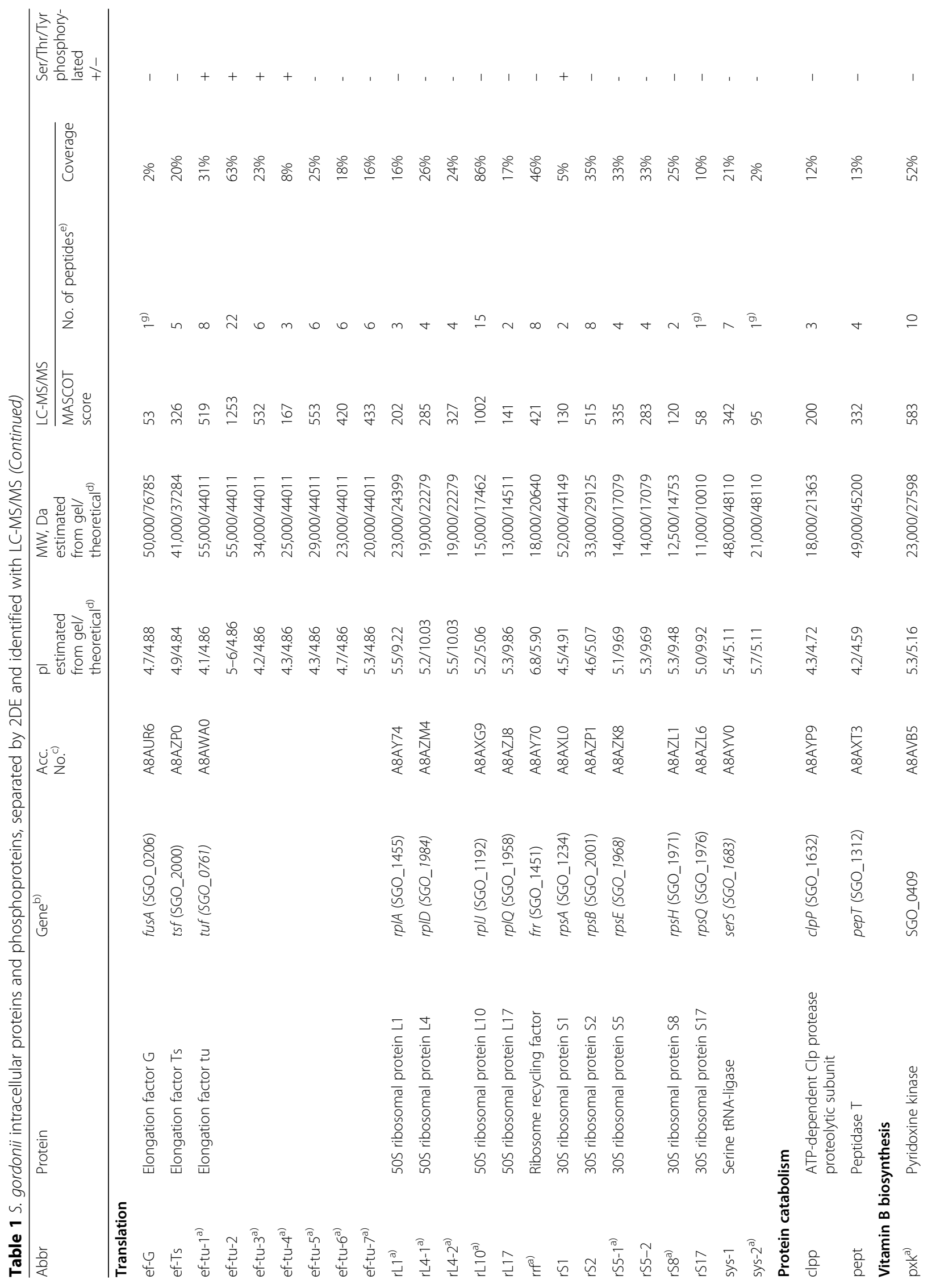




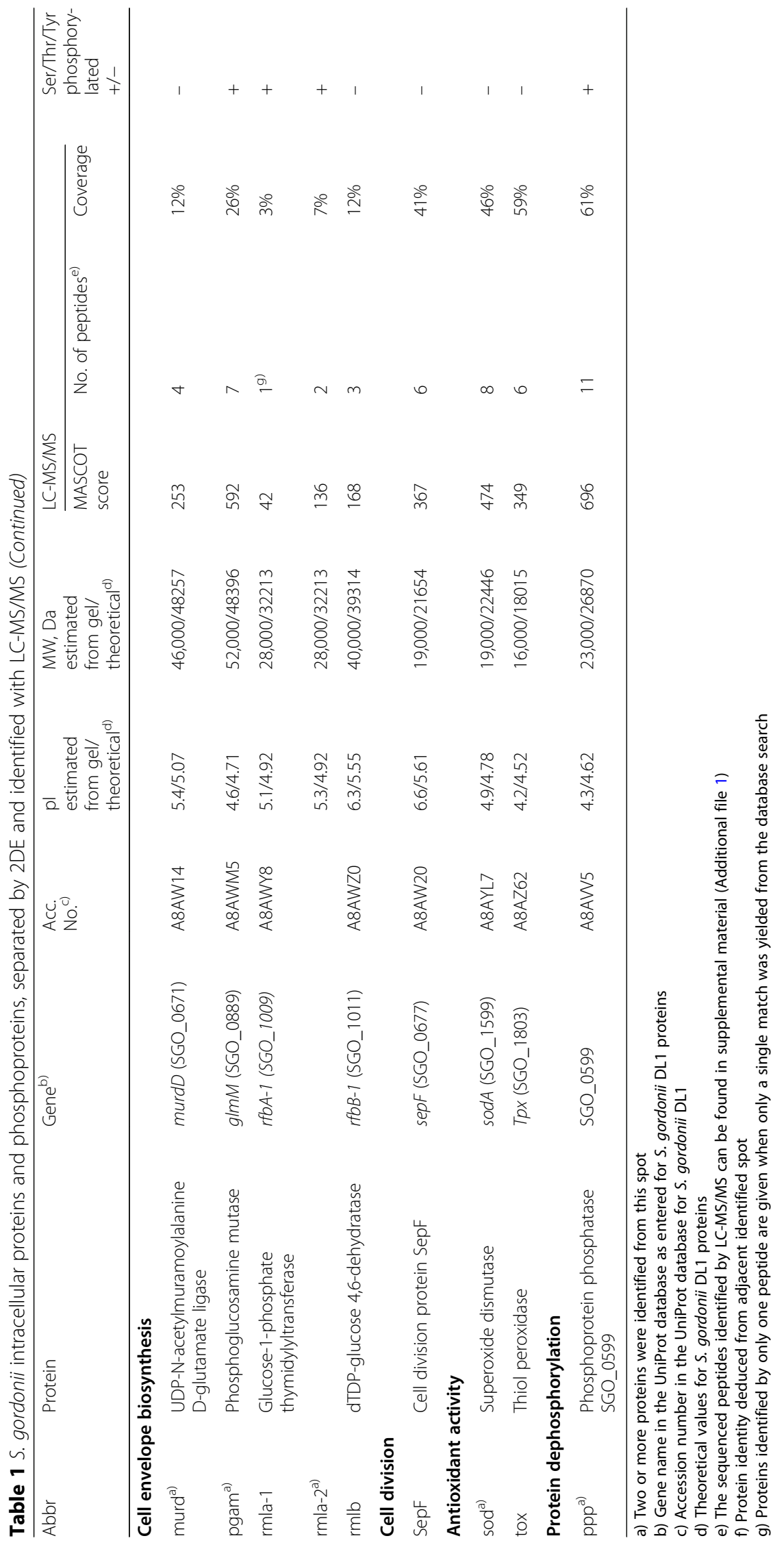




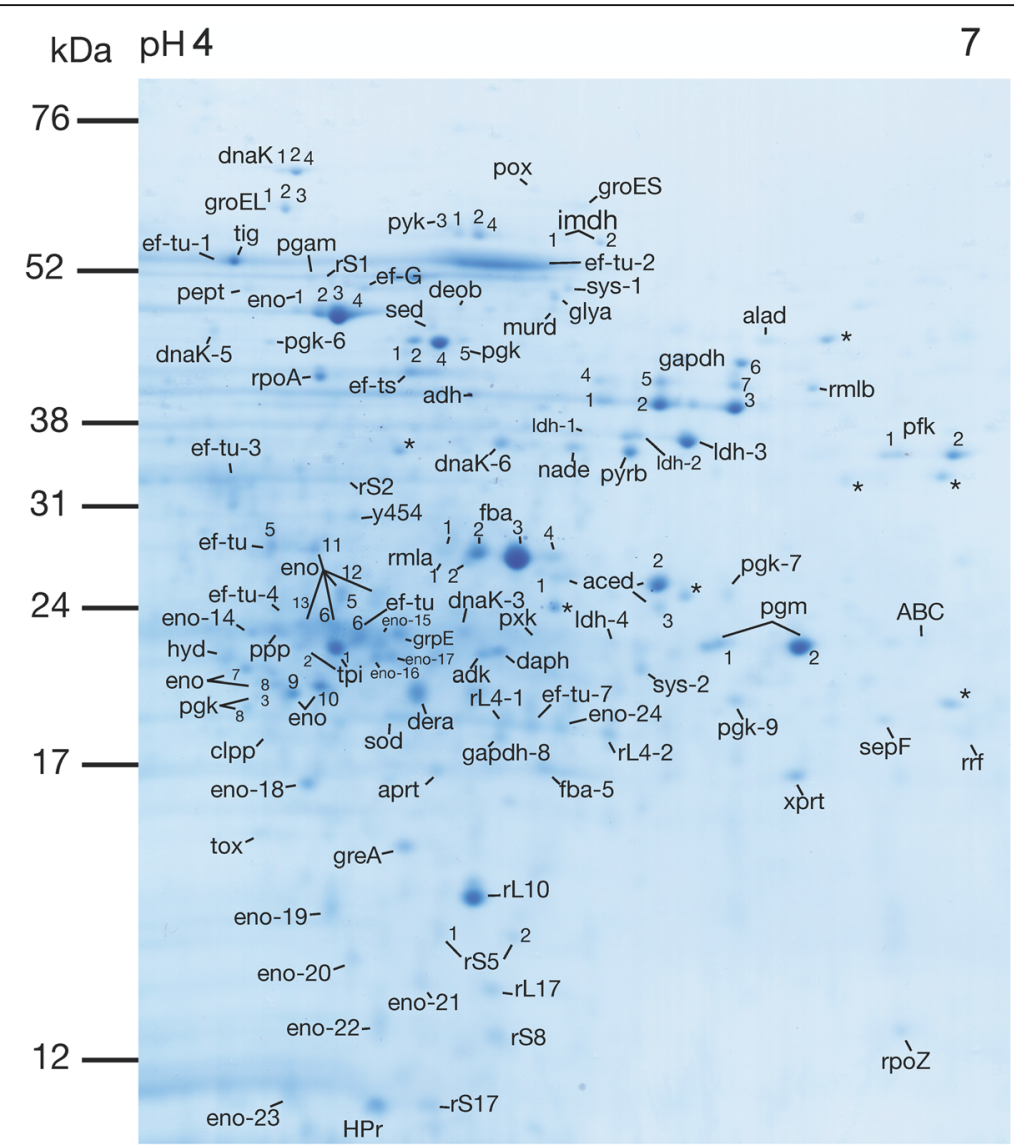

Fig. 1 Representative 2DE protein expression profile extracted from S. gordonii DL1, visualized with Coomassie Brilliant Blue stain. Proteins identified by mass spectrometry are indicated (abbreviations are listed in Table 1). Spots with no significant hits in the Mascot database search are labelled with an asterisk $\left(^{*}\right)$. Gels were produced in triplicates from three different cultures of S. gordonii DL1

rS1 were all present as single phosphorylated species, and one of the two species of imdh was phosphorylated. Like enolase, ef-tu was found at several pIs, of which four were phosphorylated. Rmla was detected as two phosphorylated species. Three phosphorylated chaperones were identified. Six species of DnaK were identified, three of which were phosphorylated. GroEL was present as three species, two of which were phosphorylated. Tig was present as a single phosphorylated species. The protein phosphatase SGO_0599 (ppp) was detected as one phosphorylated species.

\section{Comparison of Ser/Thr/Tyr phosphoproteomes to other bacteria as detected with Pro-Q Diamond Phosphoprotein gel stain on 2DE-gels}

To investigate whether the identified phosphoproteome of S. gordonii DL1 coincided with phosphoproteomes of other bacteria, literature searches were performed in the PubMed, Web of Science and Cochrane databases. Six studies were identified that examined the global Ser/Thr/ Tyr phosphoproteomes in human commensal or pathogenic bacteria using 2DE gels and Pro-Q Diamond stain.
Two studies on the model organism Bacillus subtilis were also found and included (Table 2). From planktonic cells grown under varying conditions, the previous studies revealed in total 27 and 29 putative Ser/Thr/Tyr phosphorylated proteins in B. subtilis, 15 in L. rhamnosus, 51 in Neisseria meningitidis, 73 in Staphylococcus aureus, and between 10 and 26 in different species of mycoplasma. All phosphoproteins identified in the current study except for three (pfk, rmla, ppp), were also detected as Ser/Thr/Tyr-phosphorylated in those studies, with varying occurrences. The number of phosphorylated proteins in S. gordonii DL1 detected in this study make up approximately $1 \%$ of the total number of annotated proteins in the UniProt database [45] for this species. This corresponds well to the other species tested with similar methodology, whose Ser/Thr/Tyrphosphoproteomes as detected with Pro-Q Diamond stain varied between 0.7 to $2.6 \%$ of the total proteomes. Confirmed or putative Ser/Thr/Tyr phosphorylation sites in all proteins identified as phosphorylated in this study or homologues, except for rmla and ppp, were found in the literature (Table 2). 


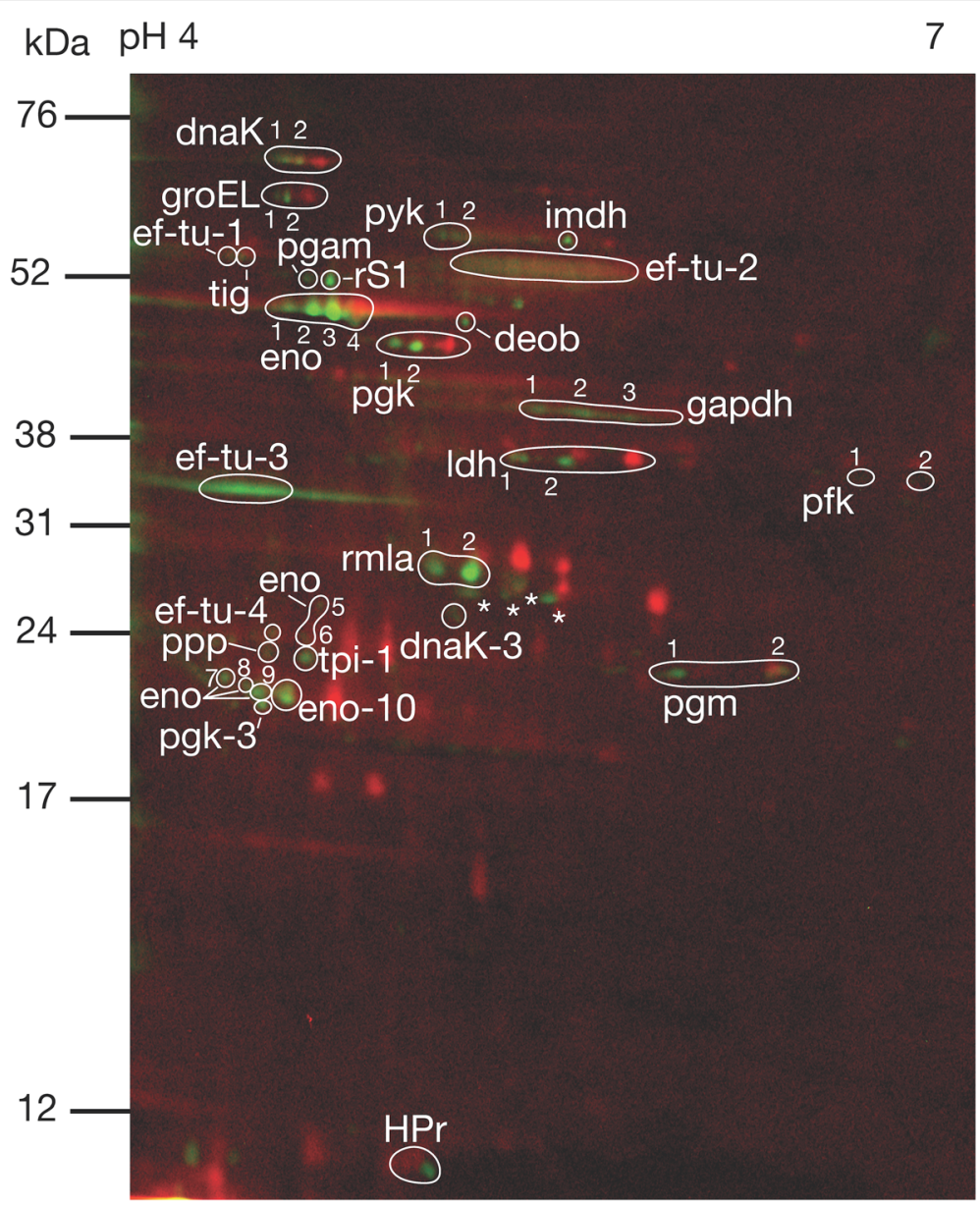

Fig. 2 Representative 2DE phosphoprotein profile extracted from S. gordonii DL1. The red stain indicates intracellular proteins visualized with T-Rex Protein Labelling kit detecting lysine residues. The green stain indicates phosphorylated proteins visualized with Pro-Q Diamond Phosphoprotein Gel Stain detecting phosphate groups attached to serine, threonine or tyrosine residues by O-phosphorylation. Phosphorylated proteins identified by mass spectrometry are indicated (abbreviations are listed in Table 1). Phosphorylated spots with no significant hits in the Mascot database search are labelled with an asterisk $(*)$. Gels were produced in triplicates from three different cultures of S. gordonii DL1

Of the 19 identified putative phosphoproteins in $S$. gordonii DL1, 13 were replicated in B. subtilis, 10 in $S$. aureus, 8 in $N$. meningitidis, 7 in L. rhamnosus, 8 in $M$. penetrans, 5 in M. pneumoniae, 4 in M. genitalium and 2 in M. gallisepticum. As in S. gordonii DL1, several of the phosphorylated proteins were also present at two or more $\mathrm{pIs}$ in these bacteria (Table 2).

\section{Discussion}

\section{Ser/Thr/Tyr phosphoproteome of S. gordonii DL1}

Putative Ser/Thr/Tyr phosphorylated intracellular proteins in S. gordonii DL1 were identified from 2DE gels using Pro-Q Diamond stain and LC-MS/MS. From the 49 phosphorylated spots detected, $19 \mathrm{Ser} / \mathrm{Thr} / \mathrm{Tyr}$ phosphoproteins were identified in S. gordonii. Determined or putative phosphorylation sites on Ser, Thr and/or Tyr in all phosphorylated proteins or homologues except for two, rmla and ppp, were found in the literature (Table 2).
A variety of cellular processes were associated with the phosphoproteins identified in S. gordonii DL1 (Fig. 3). This supports the notion that Ser/Thr/Tyr phosphorylation events are integrated in the pathways that regulate different cellular responses in this species. Many of the phosphorylated proteins were present at two or more $\mathrm{p} I \mathrm{~s}$ in S. gordonii. As is evident from Table 2, this is a common occurrence in other bacteria as well. Variably phosphorylated species of proteins are of interest because they may differ in function [21] and hence be of biological relevance. With $2 \mathrm{DE}$, although laborious, the occurrence of physiologically distinct forms of one protein can be readily visualized in a more "hands on", comprehensible overview of the present proteomic profile, were differently modified protein species often occur at adjacent pIs. Studies on deletion mutants can be employed to investigate the role of specific kinases/phosphatases on phenotypic presentation or different 


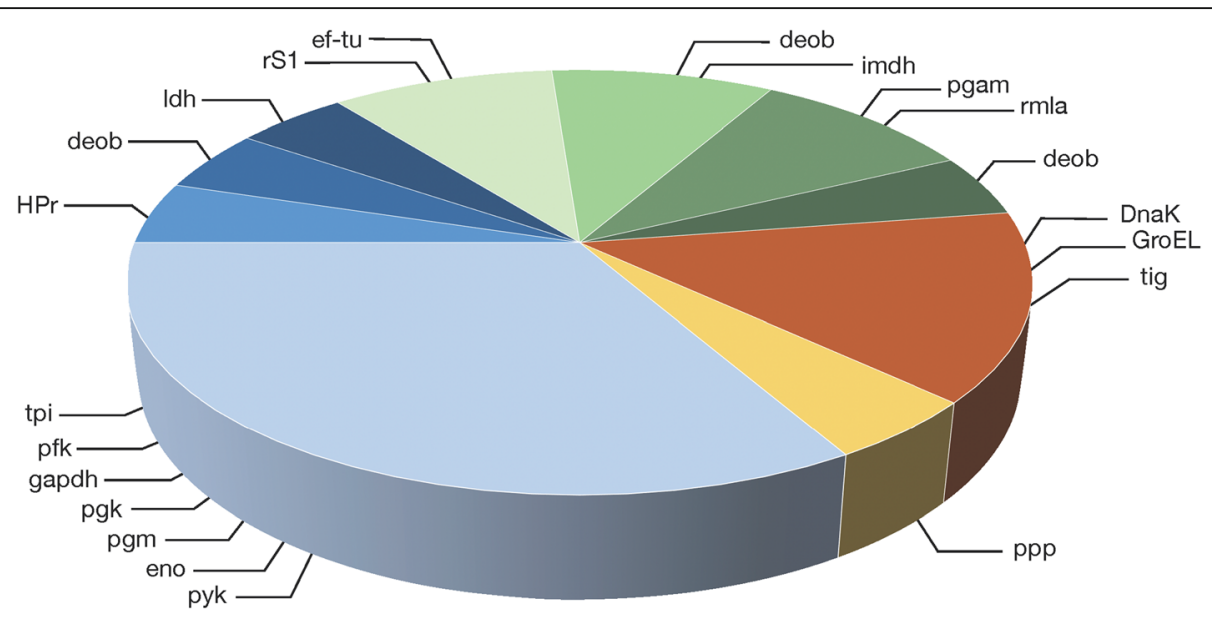

Fig. $3 \mathrm{Ser} / \mathrm{Thr} / T y r$ O-phosphorylated proteins involved in various cellular functions in S. gordonii DL1. Blue slices; carbon metabolism. Green slices; biosynthesis. Orange slice; chaperone function. Yellow slice; protein dephosphorylation. $\square$ glycolysis, $\square$ carbohydrate transport, $\square$ pentose phosphate

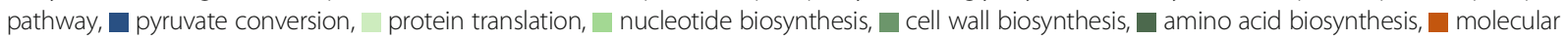
chaperone function, - protein dephosphorylation

bacterial functions [46]. The current material constitutes a first step towards future studies that may utilize such targeted approaches. Studies of this character can be carried out from any perspective of microbial physiology and biological interaction of interest. Future studies using clinical isolates as well as biofilm growth flow cell models with saliva as a nutritious substrate are also of interest to increase the resemblance to in vivo conditions.

\section{Core phosphoproteome}

The total number of identified Ser/Thr/Tyr phosphorylated proteins as detected with the Pro-Q Diamond stain in other bacteria grown in various growth conditions was between 10 and 73 [19, 27, 28, 32, 33, 37, 40, 42], making up between 0.7 to $2.6 \%$ of the total proteomes as annotated in the UniProt database [45]. This is in accordance with the 19 phosphoproteins identified in $S$. gordonii DL1 (approximately 1\% of the total proteome). All phosphoproteins identified in the current study except for three (pfk, rmla, ppp) were also previously detected as Ser/Thr/Tyr-phosphorylated with the Pro-Q Diamond stain in other bacteria (Table 2). Proteins that are consistently found in their phosphorylated state across several species and growth conditions may represent a core phosphoproteome profile shared by many bacteria. The mapping of such a core phosphoproteome may facilitate the identification of phenotypic characteristics that deviate from this core pattern. Identification of distinct phenotype phosphorylation patterns that reflect microbial activities may be crucial for pursuing a further understanding of biofilm formation and colonization of the commensal microbiota. Based on our findings, pfk, rmla and ppp represent possible proteins of interest for further investigation. Two phosphorylated protein species of pfk were detected in S. gordonii. In Streptococcus pneumoniae, pfk was found to be phosphorylated on a tyrosine residue, and phosphorylation of this enzyme was suggested to be involved in regulation of the metabolic flux in the cell [31]. One phosphorylated protein species of ppp was detected in S. gordonii. The phosphatase stp1 in Streptococcus agalactiae was identified as a homologue to S. gordonii ppp (100\% similarity) in the UniProt.org database [45]. Stp1 is involved in group B streptococcal virulence [47]. Two phosphorylated protein species of rmla was identified in S. gordonii. Activation and deactivation of rmla is an important regulating mechanism of peptidoglycan biosynthesis in gram positive bacteria, making it an interesting candidate in the search for new antibiotics [48]. Hardly anything can be found in the literature about potential regulation of catalytic activity by phosphorylation of rmla, but the current findings suggest that Ser/Thr/Tyr phosphorylation events are involved. These three proteins represent possible candidates for uniquely phosphorylated proteins in S. gordonii, however, because phosphorylation patterns are dependent on growth conditions, further experiments comparing the phosphoproteomes of different species grown in the same environments are needed.

\section{Phosphoproteins in S. gordonii DL1 involved in carbohydrate transport and metabolism}

The carbohydrate transporting protein HPr was detected as Ser/Thr/Tyr phosphorylated in S. gordonii. HPr is a known phosphoprotein with roles in the phosphotransferase system (PTS), for uptake and phosphorylation of certain carbohydrates in the central carbon metabolism. 
Table 2 Comparison to Ser/Thr/Tyr phosphoproteomes of other bacteria as detected with Pro-Q Diamond Phosphoprotein Gel Stain on 2DE gels

\begin{tabular}{|c|c|c|}
\hline Protein & $\begin{array}{l}\text { Protein also detected as phosphorylated } \\
\text { with Pro-Q Diamond in }\end{array}$ & \\
\hline \multicolumn{3}{|c|}{ Carbohydrate transport } \\
\hline $\operatorname{HPr}^{\mathrm{b}}[7,25,26]$ & $\begin{array}{l}\text { B. subtilis } 168 \operatorname{trpC2}[27] \\
\text { M. penetrans GTU-54 [28] }\end{array}$ & $\begin{array}{l}1 \\
1\end{array}$ \\
\hline \multicolumn{3}{|l|}{ Glycolysis } \\
\hline $\operatorname{tpi}^{b}[29,30]$ & $\begin{array}{l}\text { L. rhamnosus GG (ATCC 53103) [19] } \\
\text { M. penetrans GTU-54 [28] }\end{array}$ & $\begin{array}{l}1 \\
1\end{array}$ \\
\hline $\mathrm{pfk}^{\mathrm{b}}[31]$ & - & - \\
\hline gapdh $^{\mathrm{b}}[29,30]$ & $\begin{array}{l}\text { B. subtilis } 168 \operatorname{trpC2} \text { [27] } \\
\text { L. rhamnosus GG (ATCC 53103) [19] } \\
\text { S. aureus COL [32] } \\
\text { N. meningitidis Z4970 (serogroup A) [33] } \\
\text { M. penetrans GTU-54 [28] }\end{array}$ & $\begin{array}{l}1 \\
2 \\
3 \\
2 \\
1\end{array}$ \\
\hline $\operatorname{pgk}^{\mathrm{b}}[29,34,35]$ & $\begin{array}{l}\text { B. subtilis } 168 \text { trpC2 [27] } \\
\text { L. rhamnosus GG (ATCC 53103) [19] } \\
\text { N. meningitidis Z4970 (serogroup A) [33] } \\
\text { S. aureus COL [32] }\end{array}$ & \\
\hline $\operatorname{pgm}^{\mathrm{b}}[29,34]$ & $\begin{array}{l}\text { B. subtilis } 168 \operatorname{trpC2}[27] \\
\text { S. aureus COL [32] } \\
\text { M. penetrans GTU-54 [28] }\end{array}$ & $\begin{array}{l}2 \\
3 \\
1\end{array}$ \\
\hline
\end{tabular}$$
\text { Number of phosphorylated }
$$$$
\text { protein species }
$$

eno ${ }^{\mathrm{b}}[20,29,30,34,36]$

pyk $^{\mathrm{b}}[29,30,34,38,39]$

$$
\begin{aligned}
& \text { B. subtilis } 168 \operatorname{trpC2}[27] \\
& \text { B. subtilis } 168 \operatorname{trpC2}[37] \\
& \text { S. aureus COL [32] } \\
& \text { N. meningitidis Z4970 (serogroup A) [33] } \\
& \text { B. subtilis } 168 \operatorname{trpC2} \text { [27] } \\
& \text { B. subtilis } 168 \operatorname{trpC2~[37]~} \\
& \text { L. rhamnosus GG (ATCC 53103) [19] } \\
& \text { S. aureus COL [32] } \\
& \text { M. penetrans GTU-54 [28] }
\end{aligned}
$$

\section{Pyruvate conversion}

$\operatorname{ldh}^{\mathrm{a}}[29,35]$

M. genitalium G37 (ATCC 33530) [40]

M. pneumoniae M129-B170 (ATCC 29343) [40]

Pentose phosphate pathway, amino acid and nucleotide biosynthesis

deob $^{b}[34,35]$

S. aureus $\mathrm{COL}$ [32]

B. subtilis 168 trpC2 [27]

2

Nucleotide biosynthesis

imdh $^{\mathrm{b}}$ [41]

B. subtilis $168 \operatorname{trpC2}[27]$

Molecular chaperone activity

DnaK ${ }^{\mathrm{a}}[30,34]$

B. subtilis 168 trpC2 [27]

N. meningitidis Z4970 (serogroup A) [33]

M. penetrans GTU-54 [28]

M. gallisepticum S6 [42]

M. genitalium G37 (ATCC 33530) [40]

M. pneumoniae M129-B170 (ATCC 29343) [40]

$\operatorname{GroEL}^{\mathrm{b}}[30,35,39]$

B. subtilis $168 \operatorname{trpC2}$ [27]

L. rhamnosus GG (ATCC 53103) [19]

N. meningitidis Z4970 (serogroup A) [33]

M. penetrans GTU-54 [28]

M. gallisepticum $\mathrm{S} 6$ [42]

M. genitalium G37 (ATCC 33530) [40]

M. pneumoniae M129-B170 (ATCC 29343) [40]
3

3
2

1 
Table 2 Comparison to Ser/Thr/Tyr phosphoproteomes of other bacteria as detected with Pro-Q Diamond Phosphoprotein Gel Stain on 2DE gels (Continued)

\begin{tabular}{|c|c|c|}
\hline Protein & $\begin{array}{l}\text { Protein also detected as phosphorylated } \\
\text { with Pro-Q Diamond in }\end{array}$ & $\begin{array}{l}\text { Number of phosphorylated } \\
\text { protein species }\end{array}$ \\
\hline $\operatorname{Tig}^{\mathrm{b}}[19]$ & $\begin{array}{l}\text { L. rhamnosus GG (ATCC 53103) [19] } \\
\text { B. subtilis } 168 \operatorname{trpC2~[27]~} \\
\text { B. subtilis } 168 \operatorname{trpC2~[37]~} \\
\text { S. aureus COL [32] } \\
\text { N. meningitidis Z4970 (serogroup A) [33] } \\
\text { M. pneumoniae M129-B170 (ATCC 29343) [40] }\end{array}$ & $\begin{array}{l}1 \\
1 \\
1 \\
1 \\
1 \\
1\end{array}$ \\
\hline \multicolumn{3}{|c|}{ Protein translation } \\
\hline ef-tu $[30,43]$ & $\begin{array}{l}\text { B. subtilis } 168 \operatorname{trpC2}[27] \\
\text { B. subtilis } 168 \operatorname{trpC2} \text { [37] } \\
\text { S. aureus COL [32] } \\
\text { N. meningitidis Z4970 (serogroup A) [33] } \\
\text { M. penetrans GTU-54 [28] } \\
\text { M. genitalium G37 (ATCC 33530) [40] } \\
\text { M. pneumoniae M129-B170 (ATCC 29343) [40] }\end{array}$ & $\begin{array}{l}1 \\
1 \\
1 \\
2 \\
1 \\
1 \\
1\end{array}$ \\
\hline$r S 1^{b}[19]$ & $\begin{array}{l}\text { L. rhamnosus GG (ATCC 53103) [19] } \\
\text { N. meningitidis Z4970 (serogroup A) [33] }\end{array}$ & $\begin{array}{l}1 \\
2\end{array}$ \\
\hline \multicolumn{3}{|c|}{ Cell envelope biosynthesis } \\
\hline $\operatorname{pgam}^{a}[44]$ & S. aureus COL [32] & 2 \\
\hline rmla & - & - \\
\hline \multicolumn{3}{|c|}{ Protein dephosphorylation } \\
\hline ppp & - & - \\
\hline
\end{tabular}

a Phosphorylation site on Ser/Thr/Tyr identified in S. gordonii DL1 according to the UniProt.org database [45]

${ }^{\mathrm{b}} \mathrm{Ser} / \mathrm{Thr} / \mathrm{Tyr}$ phosphorylation site suggested in other species, references are listed in parenthesis

The PTS has a high affinity for glucose, and a preference for glucose over alternative carbohydrates. HPr carries known phosphorylation sites on histidine, per se involved in the phosphotransfer catalytic activity, and serine, involved in the regulation of catalytic phosphotransfer activity [49]. Phosphorylation on HPr serine reduces the phosphotransfer activity, thereby reducing the uptake of PTS-carbohydrates, while simultaneously enhancing the uptake of alternative carbohydrates [7, 26, 49]. In this way, phosphorylation events on $\mathrm{HPr}$ can regulate both the quantity and types of carbohydrates that are processed by the cell. Seven glycolytic proteins (tpi, pfk, gapdh, pgk, pgm, eno, pyk), as well as ldh, involved in pyruvate conversion, were Ser/Thr/Tyr phosphorylated in S. gordonii.

Prokaryotes have been suggested to regulate glycolytic activity rapidly and reversibly through protein phosphorylation and dephosphorylation in response to environmental changes $[12,13]$. Our findings indicate that these mechanisms are present in $S$. gordonii as well. Aside from controlling the metabolic rate and character of the metabolic end products of glycolysis, e.g. by activation of ldh, regulation of some glycolytic enzymes, e.g. tpi, controls the switch between different metabolic pathways $[50,51]$. Regulation of enzymes with reversible catalytic function, e.g. pgk, eno, may enable switching between catabolism and anabolism [45]. Rapid and reversible regulation of carbohydrate transport, control of rate of glycolysis, and alternative carbohydrate metabolizing pathways by phosphorylation, increase cell fitness by enabling adaptation of the cell metabolism in response to variations in carbohydrate concentration. Thereby, damage from processes such as sugar killing can be mitigated $[8,9,12]$. Our findings indicate that Ser/Thr/Tyr phosphorylation is involved in regulating the activities of these proteins. Control of glycolysis not only by the levels of metabolic substrates and products, but by transduction of a variety of other signals through enzyme phosphorylation events, suggests a high complexity of metabolic control in S. gordonii. This supports the idea that integration of metabolic activity and environmental factors in bacterial cells is more convoluted than previously believed.

\section{Phosphoproteins in S. gordonii DL1 involved in acid tolerance response}

To cope with the intermittent fluctuations in $\mathrm{pH}$ that naturally occur in oral biofilms, partly as a consequence of accumulation of lactic acid and other acids from the central carbon metabolism, oral streptococci employ the socalled acid tolerance response (ATR) [4, 10, 11]. Aside from responsive regulation of carbohydrate transport and metabolism, increased molecular chaperone activity comprises another important aspect of the ATR in oral streptococci $[4,8]$. The chaperones represent the group of proteins most frequently detected as Ser/Thr/Tyr 
phosphorylated in other species (Table 2). In the current study, S. gordonii displayed three phosphorylated molecular chaperones (DnaK, GroEL, tig). Ser/Thr/Tyr phosphorylation has been suggested to activate all these three chaperones in bacteria $[27,37,39,52]$. By modulating the character and acidity of metabolic end products that accumulate locally, while retaining effective metabolism and other cellular functions at lower environmental $\mathrm{pH}$ with the help of ATR responses, cells increase their competitiveness towards less aciduric species [53]. From an evolutionary point of view, these mechanisms may have contributed to the long-term survival of these species in the strenuous oral environment.

\section{Phosphoproteins in S. gordonii DL1 involved in biosynthesis}

Six phosphorylated proteins involved in biosynthesis were identified in S. gordonii DL1 (deob, imdh, ef-tu, $\mathrm{rS1}$, pgam, rmla). These proteins are involved in amino acid, nucleotide and cell wall biosynthesis, as well as protein translation (Table 1). Except for the chaperones, ef-tu was the protein most commonly detected with Pro-Q Diamond stain on 2DE gels in the previously studied bacteria (Table 2). Phosphorylation on a threonine residue in Escherichia coli ef-tu seems to inactivate the protein by decoupling the tRNA from the ribosome A-site [54, 55], triggering a rapid inhibition of protein translation. In contrast, phosphorylation on a threonine residue in the ribosomal protein $\mathrm{rS} 1$ in $E$. coli was found to activate protein translation [56]. Rapid and reversible regulation of biosynthesis through protein phosphorylation events enables the cell to be frugal regarding energy expenditure, and streamline cellular functions by modification of biomolecule production.

\section{Moonlighting and multisite regulation of identified phosphoproteins}

Several of the proteins identified as phosphorylated in $S$. gordonii DL1 have known moonlighting functions, often in adhesion, e.g. tpi [57], gapdh [58], eno [59], and GroEL [60], alternative metabolic pathways, e.g. gapdh in iron metabolism [61], or other functions. In prokaryotes, cell surface associated enolase is involved in adhesion to host components in connective tissue or saliva [59], and retention of exported enolase on the bacterial cell surface was found to increase in acidic environments [58]. Maintaining cell adhesion during acidic shifts that may inactivate other adhesins is a tentative strategy for increased competitiveness in oral biofilms. In E. coli enolase, apart from reducing its glycolytic activity, lysine phosphorylation also prevented the enzyme export related to its moonlighting functions [62]. These findings suggest that phosphorylation of enolase may affect cell adhesion during acidic shifts. Regulation of several of the phosphoproteins identified in S. gordonii DL1, such as chaperones DnaK and GroEL, also seem to involve multisite phosphorylation events [30, 34, 39, 63]. This further supports the idea that regulation of cellular activities in prokaryotes is complex and involves integrated patterns of signal transduction.

\section{Conclusion}

This study clearly shows that Ser/Thr/Tyr phosphorylation is present in an array of cytoplasmic proteins from the oral commensal S. gordonii. In total, 61 intracellular proteins were identified in S. gordonii DL1, and 19 of these turned out to be present as phosphorylated. Most of the phosphorylated proteins are involved in the carbon metabolism, specifically related to glycolysis, which is no surprise for this saccharolytic oral streptococcus. Ser/Thr/Tyr phosphorylation presents a possible mechanism for regulation of multiple cellular processes in $S$. gordonii, and phosphorylated proteins species were often present at several $\mathrm{p} I \mathrm{~s}$ with potential variation in biological function. Many similarities were found between the identified phosphoproteome of S. gordonii DL1 and that of previously studied species, despite differences in basic cell physiology and the growth conditions applied. Identification of core regulatory pathways involved in the interaction between bacteria and their environment should provide useful insights regarding new strategies to manage biofilm-induced diseases. Studies in microbiology are often focused on investigating the role of bacteria in disease. However, the physiology of commensals that prevent shifts towards dysbiosis are just as relevant. To investigate mechanisms of biofilm formation and homeostasis in the oral cavity, it is essential to examine bacterial responses and regulation of responses in relation to specific environmental challenges.

\section{Methods}

Bacterial strain and culture conditions

S. gordonii DL1 was routinely grown overnight in 25\% Todd-Hewitt Yeast Extract ( $1 / 4$ THYE, Becton Dickinson), at $37^{\circ} \mathrm{C}$ in $5 \% \mathrm{CO}_{2}$. Cell cultures were diluted 1:10 in $25 \%$ THYE $+20 \mathrm{mM}$ glucose $(1 / 4 \mathrm{THYE}+\mathrm{G})$ and grown as described above until the mid-exponential phase $($ OD600nm $=0.5-0.6)$ was reached. Planktonic cells were retrieved by centrifugation $\left(3000 \mathrm{rpm}, 10 \mathrm{~min}, 5^{\circ} \mathrm{C}\right)$, washed, and resuspended in a $10 \mathrm{mM}$ Tris $\mathrm{HCl}$-buffer pH 6.8 containing $1 \mathrm{mM}$ EDTA and $5 \mathrm{mM} \mathrm{MgSO}_{4}$, and stored at $-20^{\circ} \mathrm{C}$ until protein extraction.

\section{Protein extraction}

Harvested cells were subjected to three freeze-thaw cycles before washing and then resuspended in $700 \mu \mathrm{l}$ lysis buffer containing $8 \mathrm{M}$ urea, $2 \%$ (v/v) CHAPS, $64.8 \mathrm{mM}$ DTT, 2\% IPG buffer pH 4-7 (Pharmacia Amersham 
Biotech, Sweden). Ultrasonication of the samples was then performed with homogenizing $0.2 \mathrm{~mm}$ glass beads for $4 \times 5 \mathrm{~min}\left(5 \mathrm{~s}\right.$ pulses, amplitude 40 , Vibra-Cell ${ }^{\mathrm{m}}$ Ultrasonic Processor, SONICS), with alternate periods of cooling. Intact cells were sedimented by centrifugation at $17000 \times \mathrm{g}$ for $10 \mathrm{~min}$ at $4{ }^{\circ} \mathrm{C}$ and the supernatants (protein extracts) were stored at $-20^{\circ} \mathrm{C}$. The protein concentration was determined using the 2-D Quant kit (GE Healthcare Life Sciences).

\section{D gel electrophoresis}

Intracellular proteins were extracted and separated by two-dimensional sodium dodecyl sulfate-polyacrylamide gel electrophoresis (2D SDS-PAGE; 2DE) as described previously [64]. Isoelectric focusing was carried out on $18 \mathrm{~cm}$ Immobiline Dry Strips pH 4-7 (Amersham Pharmacia Biotech, Sweden) followed by gel electrophoresis on $14 \%$ polyacrylamide gels $(185 \times 200 \times 1.0 \mathrm{~mm})$. Gels for Coomassie staining were loaded with $150 \mu \mathrm{g}$ protein. Gels for fluorescent staining were loaded with $50 \mu \mathrm{g}$ protein, and proteins were pre-labelled with the T-Rex Labelling kit (NH DyeAGNOSTICS) before rehydration (see "Staining procedures" below). The gels were then fixed in the appropriate fix solution as recommended by the respective stain manufacturer (Coomassie stain 2\% acetic acid and 40\% ethanol and fluorescent stain 10\% acetic acid and 50\% ethanol). Gels for Coomassie staining were fixed for at least $1 \mathrm{~h}$ and gels for fluorescent staining were fixed overnight, protected from light. All gels were produced in triplicates from separate cell cultures.

\section{Staining procedures}

Coomassie gels were stained overnight in $300 \mathrm{ml} \mathrm{Coo-}$ massie brilliant blue staining solution containing 17\% Coomassie Brilliant Blue G - Colloidal Concentrate (Sigma) and 21\% ethanol. After staining, Coomassie gels were destained with $25 \%$ ethanol for approximately $1 \mathrm{~h}$ and stored in Ultra-High Quality water (UHQ) at $4{ }^{\circ} \mathrm{C}$ until scanning and excision of spots. For fluorescent staining, lysine residues of the general proteome were pre-labelled with T-Rex Labelling kit (NH DyeAGNOSTICS) before rehydration, to facilitate orientation of the phosphorylation profiles. Pre-labelling was performed according to the manufacturer's protocol. Briefly, $2 \mu \mathrm{l}$ TRex solvent and $50 \mu \mathrm{g}$ of the extracted proteins were transferred into a T-Rex labelling vial and incubated on ice for $30 \mathrm{~min}$. Thereafter the gels were prepared as described above. After fixation, each T-rex stained gel was washed with UHQ for $3 \times 15 \mathrm{~min}$ and pre-scanned once at $647 \mathrm{~nm}$ with a photomultiplier tube (PMT) setting of 800, pixel size $100 \mu \mathrm{m}$, before staining with Pro-Q Diamond Phosphoprotein Gel Stain (Invitrogen ${ }^{\text {Tx }}$, ThermoFisher Scientific) according to the manufacturer's instruction. Phosphoprotein staining was performed protected from light, and with minor modifications based on results from Agrawal and Thelen [65]. Each gel was stained with Pro-Q Diamond Phosphoprotein Gel Stain diluted 1:2 in UHQ to a final volume of $250 \mathrm{ml}$ for $2 \mathrm{~h}$. Gels were destained in $250 \mathrm{ml}$ Pro-Q Diamond Phosphoprotein Gel Destaining Solution (Invitrogen ${ }^{\mathrm{Tm}}$, ThermoFisher Scientific) per gel for $3 \times 30 \mathrm{~min}$ on a shaker and then washed in UHQ for $3 \times 5 \mathrm{~min}$.

\section{Phosphoimage analysis}

Phosphoimaging was performed with a Fujifilm FLA9000 (Science Imaging Scandinavia AB). T-Rex labelled proteins were visualized at $647 \mathrm{~nm}$, PMT $800,100 \mu \mathrm{m}$ (displayed as red). Pro-Q Diamond stained proteins were visualized at $532 \mathrm{~nm}$, PMT 600, $100 \mu \mathrm{m}$ (displayed as green). Phosphorylation profiles were analysed by three operators and then compared and discussed for calibration, with good concordance. Quantification of Pro-Q Diamond Phosphoprotein Gel Stain signals from phosphorylated spots was not possible due to variations between triplicates.

\section{Identification of streptococcal proteins by LC-MS/MS}

Protein spots were manually excised from Coomassie brilliant blue-stained gels and subjected to in-gel digestion with trypsin as previously described [64]. The resulting protein fragments were separated with liquid chromatography (LC) and characterized using tandem mass spectrometry (MS/MS) (Aberdeen Proteomics, University of Aberdeen). In short, proteins were treated with DTT for reduction $\left(60^{\circ} \mathrm{C}, 20 \mathrm{~min}\right)$, iodacetamide for S-alkylation $\left(25^{\circ} \mathrm{C}, 10 \mathrm{~min}\right)$ and trypsin for digestion $\left(37^{\circ} \mathrm{C}, 8 \mathrm{~h}\right)$. Following drying by rotary evaporation (SC110 Speedvac, Savant Instruments), the peptide extract was dissolved in $0.1 \%$ formic acid. Analysis of peptide solutions was carried out using an HTCultraPTM Discovery system (Bruker Daltonics) coupled to an UltiMate 3000 LC system (Dionex). Separation of tryptic peptides was performed on a monolithic capillary column $(200 \mu \mathrm{m}$ internal diameter $\times 5 \mathrm{~cm}$, Dionex $)$. The gradient consisted of $5 \%$ acetonitrile in UHQ containing $0.5 \%$ formic acid, to $37 \%$ acetonitrile in UHQ containing $0.45 \%$ formic acid over $12 \mathrm{~min}$ at a flow rate of $2.5 \mu \mathrm{l}$ $\mathrm{min}^{-1}$. Data-dependent mode was employed to acquire peptide fragment mass spectra, AutoMS (2). The scan range was $300-1500 \mathrm{~m} / \mathrm{z}$, with three averages, and up to three precursor ions that were selected from the MS scan $(100-2200 \mathrm{~m} / \mathrm{z})$. Active exclusion of precursors was performed within a $1.0 \mathrm{~min}$ window, as well as exclusion of all singly charged ions. Detection and deconvolution of peptide peaks were carried out automatically using Data Analysis software (Bruker). Mass lists in the form of Mascot Generic files were created automatically and 
used as the input for Mascot MS/MS ion searches in the NCBInr database for Firmicutes (Gram Positive Bacteria) using the Matrix Science web server [66]. Parameters were set to $0.5 \mathrm{Da}$ peptide mass tolerance, methionine oxidation and carboxyamidomethylation of cysteine. The maximum number of missed cleavages was set to 1 . Proteins were identified by at least two peptides with a Mascot score of 33 or higher, the latter as suggested by Koenig et al., 2008 [67].

\section{Literature search}

The PubMed, Web of Science and Cochrane databases were searched for studies that examined global Ser/Thr/ Tyr phosphoproteomes in human commensal and pathogenic bacteria using Pro-Q Diamond Phosphoprotein Gel Stain on 2DE gels. Studies on the model organism Bacillus subtilis were also included.

\section{Supplementary information}

Supplementary information accompanies this paper at https://doi.org/10. 1186/s12866-020-01944-y.

Additional file 1. The sequenced peptides identified by LC-MS/MS can be found in supplemental material (Additional file 1). Sequenced peptides identified by LC-MS/MS; Ser/Thr/Tyr phosphorylated protein species (Table A), and non-phosphorylated protein species (Table B).

\section{Abbreviations}

2DE: Two-dimensional gel electrophoresis; 1/4 THYE: 25\% Todd-Hewitt Yeast Extract; 1/4 THYE+G: 25\% THYE + 20 mM glucose; ATR: Acid tolerance response; MW: Molecular weight; PTS: Phosphotransferase transport system; Ser/Thr/Tyr: Serine, threonine, tyrosine; UHQ: Ultra-High Quality water

\section{Acknowledgements}

We would like to thank Agnethe Henriksson and Madeleine Blomqvist (Malmö) for their excellent technical assistance.

\section{Authors' contributions}

CR, GS and CW participated in the design and coordination of the study. CR performed the experiments and drafted the manuscript. CR, GS, and CW analyzed and interpreted the data. GS, CW and ZB provided extensive suggestions on the research as it progressed and were major contributors in revising and editing the final manuscript. All authors read and approved the final manuscript.

\section{Authors' information}

Not applicable.

\section{Funding}

This study was supported by grants from Malmö University, Sweden, supporting the interdisciplinary research programme FORESIGHT, and the Swedish Research Council (201601994). Open access funding provided by Malmö University.

\section{Availability of data and materials}

All datasets generated or analysed during this study are included in this published article and its supplementary information files, see (Additional file 1). The gel triplicates are available from the corresponding author on reasonable request.

Ethics approval and consent to participate Not applicable.
Consent for publication

Not applicable.

\section{Competing interests}

The authors declare that they have no competing interests.

\section{Author details}

${ }^{1}$ Department of Oral Biology and Pathology, Faculty of Odontology, Malmö University, 20506 Malmö, Sweden. '2Department of Biomedical Science, Malmö University, 20506 Malmö, Sweden.

Received: 26 June 2020 Accepted: 11 August 2020

Published online: 14 September 2020

\section{References}

1. Li J, Helmerhorst EJ, Leone CW, Troxler RF, Yaskell T, Haffajee AD, Socransky SS, Oppenheim FG. Identification of early microbial colonizers in human dental biofilm. J Appl Microbiol. 2004;97:1311-8.

2. Schachtele CF, Nobbs A, Zhang Y, Costalonga M, Herzberg MC. Oral streptococci: commensals and opportunistic pathogens. In: Hakenbeck R, Chhatwal S, editors. Molecular biology of streptococci. 1st ed. Norfolk: Horizon Bioscience; 2007. p. 411-62.

3. Knox KW, Hunter N. The role of oral bacteria in the pathogenesis of infective endocarditis. Aust Dent J. 1991;36:286-92.

4. Takahashi N, Yamada T. Acid-induced acid tolerance and acidogenicity of non-mutans streptococci. Oral Microbiol Immunol. 1999;14:43-8.

5. Stephan RM. Changes in hydrogen-ion concentrations on tooth surfaces and in carious lesions. J Am Dent Assoc. 1940;27:718-23.

6. Stephan RM. Intra-oral hydrogen-ion concentrations associated with dental caries activity. J Dent Res. 1944;23:257-66.

7. Vadeboncoeur C, Pelletier M. The phosphoenolpyruvate:sugar phosphotransferase system of oral streptococci and its role in the control of sugar metabolism. FEMS Microbiol Rev. 1997;19:187-207.

8. Lemos JAC, Abranches J, Burne RA. Responses of cariogenic streptococci to environmental stresses. Current Issues in Mol Biol. 2005;7:95-108.

9. Yamada T, Carlsson J. Regulation of lactate dehydrogenase and change of fermentation products in streptococci. J Bacteriol. 1975;124:55-61.

10. Hamilton IR, Buckley ND. Adaptation by Streptococcus mutans to acid tolerance. Oral Microbiol Immunol. 1991;6:65-71.

11. Svensäter G, Larsson UB, Greif ECG, Cvitkovitch DG, Hamilton IR. Acid tolerance response and survival by oral bacteria. Oral Microbiol Immunol. 1997;12:266-73.

12. Cozzone AJ. Protein phosphorylation in prokaryotes. Annu Rev Microbiol. 1988:42:97-125.

13. Pereira SFF, Goss L, Dworkin J. Eukaryote-like serine/threonine kinases and phosphatases in Bacteria. Microbiol Mol Biol Rev. 2011;75:192-212.

14. Hammes GG, Wu CW. Kinetics of allosteric enzymes. Annu Rev Biophys Bioeng. 1974;3:1-33.

15. Kennelly PJ, Potts M. Fancy meeting you here! A fresh look at 'prokaryotic' protein phosphorylation. J Bacteriol. 1996;178:4759-64.

16. Deutscher J, Saier MH. Ser/Thr/Tyr protein phosphorylation in bacteria - for long time neglected, now well established. J Mol Microbiol Biotechnol. 2006;9:125-31.

17. Cozzone AJ. Role of protein phosphorylation on serine/threonine and tyrosine in the virulence of bacterial pathogens. J Mol Microbiol Biotechnol. 2005;9:198-213.

18. Ge R, Shan W. Bacterial Phosphoproteomic analysis reveals the correlation between protein phosphorylation and bacterial pathogenicity. Genomics Proteomics Bioinformatics. 2011;9:119-27.

19. Koponen J, Laakso K, Koskenniemi K, Kankainen M, Savijoki K, Nyman TA, de Vos WM, Tynkkynen S, Kalkkinen N, Varmanen P. Effect of acid stress on protein expression and phosphorylation in Lactobacillus rhamnosus GG. J Proteome. 2012;75:1357-74.

20. Jers C, Pedersen MM, Paspaliari DK, Schütz W, Johnsson C, Soufi B, Macek B, Jensen PR, Mijakovic I. Bacillus subtilis BY-kinase PtkA controls enzyme activity and localization of its protein substrates. Mol Microbiol. 2010;77:287-99.

21. Cohen $P$. The regulation of protein function by multisite phosphorylation a 25 year update. Trends Biochem Sci. 2000;25:596-601.

22. Jeffery CJ. Protein species and moonlighting proteins: very small changes in a protein's covalent structure can change its biochemical function. J Proteome. 2016;134:19-24. 
23. Mimura CS, Poy F, Jacobson GR. ATP-dependent protein kinase activities in the oral pathogen Streptococcus mutans. J Cell Biochem. 1987;33:161-71.

24. Banu LD, Conrads G, Rehrauer H, Hussain H, Allan E, van der Ploeg JR. The Streptococcus mutans serine/threonine kinase, $\mathrm{PknB}$, regulates competence development, bacteriocin production, and cell wall metabolism. Infect Immun. 2010;78:2209-20.

25. Frey N, Nessler S, Fieulaine S, Vaillancourt K, Frenette M, Vadeboncoeur C. The HPr(Ser) kinase of Streptococcus salivarius: a hexameric bifunctional enzyme controlled by glycolytic intermediates and inorganic phosphate. FEMS Microbiol Lett. 2003:224:67-72.

26. Reizer J, Romano AH, Deutscher J. The role of phosphorylation of HPr, a phosphocarrier protein of the phosphotransferase system, in the regulation of carbon metabolism in gram-positive bacteria. J Cell Biochem. 1993;51:19-24.

27. Eymann C, Becher D, Bernhardt J, Gronau K, Klutzny A, Hecker M. Dynamics of protein phosphorylation on Ser/Thr/Tyr in Bacillus subtilis. Proteomics. 2007:7:3509-26

28. Ferrer-Navarro M, Gómez A, Yanes O, Planell R, Avilés FX, Piñol J, Pons JAP, Querol E. Proteome of the bacterium Mycoplasma penetrans. J Proteome Res. 2006:5:688-94.

29. Macek B, Mijakovic I, Olsen JV, Gnad F, Kumar C, Jensen PR, Mann M. The serine/threonine/tyrosine Phosphoproteome of the model bacterium Bacillus subtilis. Mol Cell Proteomics. 2007;6:697-707.

30. Misra SK, Milohanic E, Aké F, Mijakovic I, Deutscher J, Monnet V, Henry C. Analysis of the serine/threonine/tyrosine phosphoproteome of the pathogenic bacterium Listeria monocytogenes reveals phosphorylated proteins related to virulence. Proteomics. 2011;11:4155-65.

31. Ahmad Z, Morona R, Standish AJ. In vitro characterization and identification of potential substrates of a low molecular weight protein tyrosine phosphatase in Streptococcus pneumoniae. Microbiol. 2018;164:697-703.

32. Bäsell K, Otto A, Junker S, Zühlke D, Rappen G-M, Schmidt S, Hentschker C, Macek B, Ohlsen K, Hecker M, Becher D. The phosphoproteome and its physiological dynamics in Staphylococcus aureus. Int J Med Microbiol. 2014;304:121-32.

33. Bernardini G, Laschi M, Serchi T, Arena S, D'Ambrosio C, Braconi D, Scaloni A, Santucci A. Mapping phosphoproteins in Neisseria meningitidis serogroup a. Proteomics. 2011;11:1351-8.

34. Macek B, Gnad F, Soufi B, Kumar C, Olsen JV, Mijakovic I, Mann M. Phosphoproteome analysis of $E$. coli reveals evolutionary conservation of bacterial Ser/Thr/Tyr phosphorylation. Mol Cell Proteomics. 2008;7:299-307.

35. Soufi B, Gnad F, Jensen PR, Petranovic D, Mann M, Mijakovic I, Macek B. The Ser/Thr/Tyr phosphoproteome of Lactococcus lactis IL1403 reveals multiply phosphorylated proteins. Proteomics. 2008:8:3486-93.

36. Virmani R, Sajid A, Singhal A, Gaur M, Joshi J, Bothra A, Garg R, Misra R, Singh VP, Molle V, Goel AK, Singh A, Kalia VC, Lee JK, Hasija Y, Arora G, Singh $Y$. The Ser/Thr protein kinase PrkC imprints phenotypic memory in Bacillus anthracis spores by phosphorylating the glycolytic enzyme enolase. J Biol Chem. 2019:294:8930-41.

37. Lévine A, Vannier F, Absalon C, Kuhn L, Jackson P, Scrivener E, Labas V, Vinh J, Courtney P, Garin J, Séror SJ. Analysis of the dynamic Bacillus subtilis Ser/ Thr/Tyr phosphoproteome implicated in a wide variety of cellular processes. Proteomics. 2006;6:2157-73.

38. Singh DK, Singh PK, Tiwari S, Singh SK, Kumari R, Tripathi DK, Srivastava KK. Phosphorylation of pyruvate kinase a by protein kinase J leads to the altered growth and differential rate of intracellular survival of mycobacteria. Appl Microbiol Biotechnol. 2014;98:10065-76.

39. Arora G, Sajid A, Virmani R, Singhal A, Kumar CMS, Dhasmana N, Khanna T, Maji A, Misra R, Molle V, Becher D, Gerth U, Mande SC, Singh Y. Ser/Thr protein kinase PrkC-mediated regulation of GroEL is critical for biofilm formation in Bacillus anthracis. NPJ Biofilms Microbiomes. 2017:3:7.

40. Su HC, Hutchison CA, Giddings MC. Mapping phosphoproteins in Mycoplasma genitalium and Mycoplasma pneumoniae. BMC Microbiol. 2007;7:63.

41. Rajagopal L, Vo A, Silvestroni A, Rubens CE. Regulation of purine biosynthesis by a eukaryotic-type kinase in Streptococcus agalactiae. Mol Microbiol. 2005;56:1329-46

42. Demina IA, Serebryakova MV, Ladygina VG, Rogova MA, Zgoda VG, Korzhenevskyi DA, Govorun VM. Proteome of the bacterium Mycoplasma gallisepticum. Biochem. 2009;74:165-74.

43. Lippmann C, Lindschau C, Vijgenboom E, Schroder W, Bosch L, Erdmann VA. Prokaryotic elongation factor Tu is phosphorylated in vivo. J Biol Chem. 1993;268:601-7
44. Jolly L, Ferrari P, Blanot D, van Heijenoort J, Fassy F, Mengin-Lecreulx D. Reaction mechanism of phosphoglucosamine mutase from Escherichia coli. Eur J Biochem. 1999;262:202-10.

45. UniProt database. www.uniprot.org. Accessed 18 Aug 2020.

46. Bender MH, Cartee RT, Yother J. Positive correlation between tyrosine phosphorylation of CpsD and capsular polysaccharide production in Streptococcus pneumoniae. J Bacteriol. 2003;185:6057-66.

47. Burnside K, Lembo A, Harrell MI, Gurney M, Xue L, Binh Tran NT, Connelly JE, Jewell KA, Schmidt BZ, de los Reyes M, Tao WA, Doran KS, Rajagopal L. Serine/threonine phosphatase Stp1 mediates post-transcriptional regulation of hemolysin, autolysis, and virulence of group B Streptococcus. J Biol Chem. 2011;286:44197-210.

48. Blankenfeldt W, Asuncion M, Lam JS, Naismith JH. The structural basis of the catalytic mechanism and regulation of glucose-1-phosphate thymidylyltransferase (Rm|A). EMBO J. 2000;19:6652-63.

49. Deutscher J, Kessler U, Alpert CA, Hengstenberg W. Bacterial Phosphoenolpyruvate-dependent Phosphotransferase system: P-Ser-HPr and its possible regulatory function. Biochemistry. 1984;23:4455-60.

50. Kang TS, Korber DR, Tanaka T. Regulation of dual glycolytic pathways for fructose metabolism in heterofermentative Lactobacillus panis PM1. Appl Environ Microbiol. 2013;79:7818-26.

51. Solem C, Koebmann B, Jensen PR. Control analysis of the role of triosephosphate isomerase in glucose metabolism in Lactococcus lactis. IET Syst Biol. 2008;2:64-72.

52. Sherman MY, Goldberg AL. Heat shock of Escherichia coli increases binding of dnaK (the hsp70 homolog) to polypeptides by promoting its phosphorylation. Proc Natl Acad Sci U S A. 1993:90:8648-52.

53. Abbe K, Carlsson J, Takahashi-Abbe S, Yamada T. Oxygen and the sugar metabolism in oral streptococci. Proc Finn Dent Soc. 1991;87:477-87.

54. Pereira SFF, Gonzalez RL, Dworkin J. Protein synthesis during cellular quiescence is inhibited by phosphorylation of a translational elongation factor. Proc Natl Acad Sci U S A. 2015;112:3274-81.

55. Talavera A, Hendrix J, Versées W, Jurènas D, Van Nerom K, Vandenberk N, Singh RK, Konijnenberg A, De Gieter S, Castro-Roa D, Barth A, De Greve H, Sobott F, Hofkens J, Zenkin N, Loris R, Garcia-Pino A. Phosphorylation decelerates conformational dynamics in bacterial translation elongation factors. Sci Adv. 2018;4:9714-28.

56. Robertson ES, Nicholson AW. Phosphorylation of Escherichia coli translation initiation factors by the bacteriophage T7 protein Kinaset. Biochemistry. 1992;31:4822-7.

57. Furuya $H$, Ikeda R. Interaction of triosephosphate isomerase from Staphylococcus aureus with plasminogen. Microbiol Immunol. 2011;55:855-62.

58. Wang G, Xia Y, Cui J, Gu Z, Song Y, Chen YQ, Zhang H, Chen W. The roles of moonlighting proteins in Bacteria. Curr Issues Mol Biol. 2014;16:15-22.

59. Huberts DHEW, van der Klei IJ. Moonlighting proteins: an intriguing mode of multitasking. Biochim Biophys Acta. 2010;1803:520-5.

60. Bergonzelli GE, Granato D, Pridmore RD, Marvin-Guy LF, Donnicola D, Corthésy-Theulaz IE. GroEL of Lactobacillus johnsonii La1 (NCC 533) is cell surface associated: potential role in interactions with the host and the gastric pathogen Helicobacter pylori. Infect Immun. 2006;74:425-34.

61. Boradia VM, Raje M, Raje Cl. Protein moonlighting in iron metabolism: Glyceraldehyde-3-phosphate dehydrogenase (GAPDH). Biochem Soc Trans. 2014:42:1796-801.

62. Boël G, Pichereau V, Mijakovic I, Mazé A, Poncet S, Gillet S, Giard JC, Hartke A, Auffray Y, Deutscher J. Is 2-phosphoglycerate-dependent automodification of bacterial enolases implicated in their export? J Mol Biol. 2004;337:485-96.

63. Shi L, Ravikumar V, Derouiche A, Macek B, Mijakovic I. Tyrosine 601 of Bacillus subtilis DnaK undergoes phosphorylation and is crucial for chaperone activity and heat shock survival. Front Microbiol. 2016;7:533-46.

64. Davies JR, Svensäter G, Herzberg MC. Identification of novel LPXTG-linked surface proteins from Streptococcus gordonii. Microbiology. 2009;155:1977-88.

65. Agrawal GK, Thelen JJ. Development of a simplified, economical polyacrylamide gel staining protocol for phosphoproteins. Proteomics. 2005;5:4684-8.

66. Matrix Science web server. www.matrixscience.com. Accessed 18 Aug 2020.

67. Koenig T, Menze BH, Kirchner M, Monigatti F, Parker KC, Patterson T, Steen $J$ J, Hamprecht FA, Steen H. Robust prediction of the MASCOT score for an improved quality assessment in mass spectrometric proteomics. J Proteome Res. 2008;7:3708-17

\section{Publisher's Note}

Springer Nature remains neutral with regard to jurisdictional claims in published maps and institutional affiliations. 